\title{
A new species of the copepod genus Australoeucyclops (Crustacea: Cyclopoida: Eucyclopinae) from Western Australia shows the role of aridity in habitat shift and colonisation of ground water
}

\author{
Tomislav Karanovic ${ }^{1}$ and Danny Tang ${ }^{2}$ \\ ${ }^{1}$ University of Tasmania, School of Zoology, Locked Bag 5, Hobart, \\ Tasmania 7001, Australia. E-mail: tomislav.karanovic@utas.edu.au \\ ${ }^{2}$ University of Western Australia, Department of Zoology (M092), 35 Stirling Highway, \\ Crawley, Western Australia 6009, Australia. E-mail: copepods@graduate.uwa.edu.au
}

\begin{abstract}
A new species of the cyclopoid genus Australoeucyclops Karanovic, 2006 is described from several disjunct locations in south-western Western Australia. This is the sixth representative of this genus, which is endemic to Australia, New Zealand and Indonesia. Australoeucyclops darwini sp. nov. differs from all its congeners by its subequal apical spines on the fourth leg endopod and can also be distinguished from each species by a number of other characters. A key for identification of Australoeucyclops species is given, as well as an overview of the valid genera in the subfamily Eucyclopinae Kiefer, 1927. The habitat choice of the new species is very interesting, because it can be found only in caves in the northern part of its range, while it lives exclusively in surface waters in the south. The potential role of aridity in this habitat shift in Australia is discussed.
\end{abstract}

\section{INTRODUCTION}

The eucyclopinid copepod genus Australoeucyclops Karanovic, 2006 currently contains five taxa: A. eucyclopoides (Kiefer, 1929) from Indonesia; A. linderi (Lindberg, 1948) from South Australia; A. timmsi (Kiefer, 1969) from New South Wales, Australia; A. waiariki (Lewis, 1974) from New Zealand; and A. karaytugi Karanovic, 2006 from Western Australia (see Karanovic 2006). However, Karanovic (2006) mentioned that another as yet undescribed member of this genus existed in the Margaret River region of Western Australia. Indeed, Tang and Knott (2009) recently found this undescribed species in the Gnangara Mound region (more than $250 \mathrm{~km}$ north of Margaret River) and about $200 \mathrm{~km}$ further north near Eneabba, Western Australia. They stated that "comparisons between our specimens and a set of detailed illustrations kindly provided by Dr. Tomislav Karanovic (University of Tasmania) of the undescribed Australoeucyclops species from a dam and springs in the Margaret River area (see Eberhard 2004) revealed that these disjunct copepod populations contain individuals of the same species". As such, they deliberately refrained from describing this species and using Karanovic's proposed binomen for reasons related to rules of the International Code of Zoological Nomenclature (International Commission on Zoological Nomenclature 1999). Tang and Knott (2009) also discovered that the cyclopoid copepod specimens identified previously as Eucyclops linderi Lindberg, 1948 by Jasinska and Knott (2000) from Cabaret Cave in Yanchep National Park were also conspecific with this undescribed Australoeucyclops species. We describe this new species herein after examination of all these disjunct populations from Margaret River, Gnangara Mound and Eneabba, but we expect that further investigations of both surface and subterranean environments in this part of Western Australia will slowly fill the gaps in its known distribution. An almost complete absence of any morphological variability between these disjunct populations supports this hypothesis.

Intriguingly, the new copepod species is present only in surface water habitats in the southernmost part of its habitat, because it is absent from caves in the Margaret River region (see Eberhard 2004). In the Gnangara Mound region the new taxon was found in multiple caves and one spring, whilst near Eneabba it was found in a single cave (Tang and Knott 2009). Only a limited number of surface water habitats were surveyed, however, in the former area and surface water habitats near the latter has not yet been sampled. Notwithstanding, we explore how aridity may have influenced the potential habitat shift of this interesting cyclopoid copepod.

In the second part of this paper we examine the position of the genus Australoeucyclops in the subfamily Eucyclopinae. An overview of 
the valid genera in this subfamily showed an isolated position of the closely related genera Macrocyclops Claus, 1893 and Homocyclops Forbes, 1897, which was already suspected by Karanovic (2006). However, we refrained from formally erecting a new subfamily in the absence of a more comprehensive phylogenetic analysis.

\section{MATERIAL AND METHODS}

From the Margaret River region, specimens were obtained from two springs and one dam using a simple $500 \mu \mathrm{m}$ plankton net. Samples were sorted live under a dissecting microscope, and copepods were picked out and fixed in $70 \%$ ethanol. They were all collected by Dr Stefan M. Eberhard (Subterranean Ecology environmental consultancy) as part of his PhD project. In the Gnangara Mound region, copepods were obtained from 10 caves within Yanchep National Park, one cave (Lot 51 Cave) located about $0.5 \mathrm{~km}$ beyond the southeastern boundary of Yanchep National Park and one spring in Bullsbrook. Of the 11 Yanchep cave sites, eight contained eucalypt root mats. Samples were obtained from the 12 Gnangara Mound sites as follows: a) in each cave containing eucalypt root mats by sweeping a $70 \mu \mathrm{m}$ mesh net across submerged root mats; $b$ ) in each cave lacking eucalypt root mats by sweeping a $500 \mu \mathrm{m}$ mesh sieve along the sediment surface of epiphreatic pools; and c) at the spring by sweeping a $500 \mu \mathrm{m}$ mesh sieve along the sediment surface close to the discharge point. Each sample was placed in a plastic bag, covered with water from the site, labelled, sealed tightly and transported alive under cool, dark conditions to the laboratory. Copepods were sorted from debris under a dissecting microscope and preserved in $70-100 \%$ ethanol.

Selected specimens were each dissected, mounted on microscope slides in Faure's medium (see Stock and von Vaupel Klein 1996) and covered with a coverslip. For the urosome or the entire animal, two human hairs were mounted between the slide and coverslip so the parts would not be compressed. By manipulating the coverslip carefully by hand, the whole animal or a particular appendage could be positioned in different aspects, making possible the observation of morphological details. During the examination water slowly evaporated and appendages eventually remained in completely dry Faure's medium, ready for long term storage. All drawings were prepared using a drawing tube attached to a Leica-DMLS brightfield compound microscope, with C-PLAN achromatic objectives. Specimens that were not drawn were examined in a mixture of equal parts of distilled water and glycerol and, after examination, were again preserved in $70 \%$ ethanol. Some intact and dissected specimens were also soaked in lactic acid on wooden slides (sensu Humes and Gooding 1964) prior to examination using an Olympus BX51 compound microscope equipped with differential interference contrast. Morphological terminology follows Huys and Boxshall (1991), except for small differences in the spelling of some appendages (antennula, mandibula and maxillula instead of antennule, mandible and maxillule) to standardise the terminology for homologue appendages in different crustacean groups. Biospeleological terminology follows Humphreys (2000). The type material and some additional specimens are deposited in the Western Australian Museum (WAM) in Perth. Other material is deposited in the Australian Museum (AM) in Sydney, Tasmanian Museum and Art Gallery (TMAG) in Hobart, and Zoology Department of the University of Western Australia (UWA) in Perth.

\section{SYSTEMATICS}

\section{Order Cyclopoida Rafinesque, 1815}

Family Cyclopidae Rafinesque, 1815

Subfamily Eucyclopinae Kiefer, 1927

Genus Australoeucyclops Karanovic, 2006

Australoeucyclops Karanovic, 2006: 22.

\section{Type species}

Australoeucyclops karaytugi Karanovic, 2006, by original designation.

\section{Australoeucyclops darwini sp. nov.} Figures 1-25

Eucyclops linderi Lindberg, 1948: Jasinska and Knott, 2000: 301.

Australoeucyclops sp.: Tang and Knott, 2009: 6.

\section{Material examined}

Holotype

Australia: Western Australia: $q$ dissected on 2 slides, Margaret River region, Turners Spring, benthos and interstitial, 27 February 2002, $34^{\circ} 20^{\prime} 53^{\prime \prime}$ S, $115^{\circ} 09^{\prime} 14^{\prime \prime}$ E, S.M. Eberhard (WAM C28598).

\section{Allotype}

Australia: Western Australia: dissected on 2 slides, collected with holotype (WAM C28599).

\section{Other paratypes}

Australia: Western Australia: all collected with holotype: 2 के (WAM C28600, C28601) and 2 ㅇ 


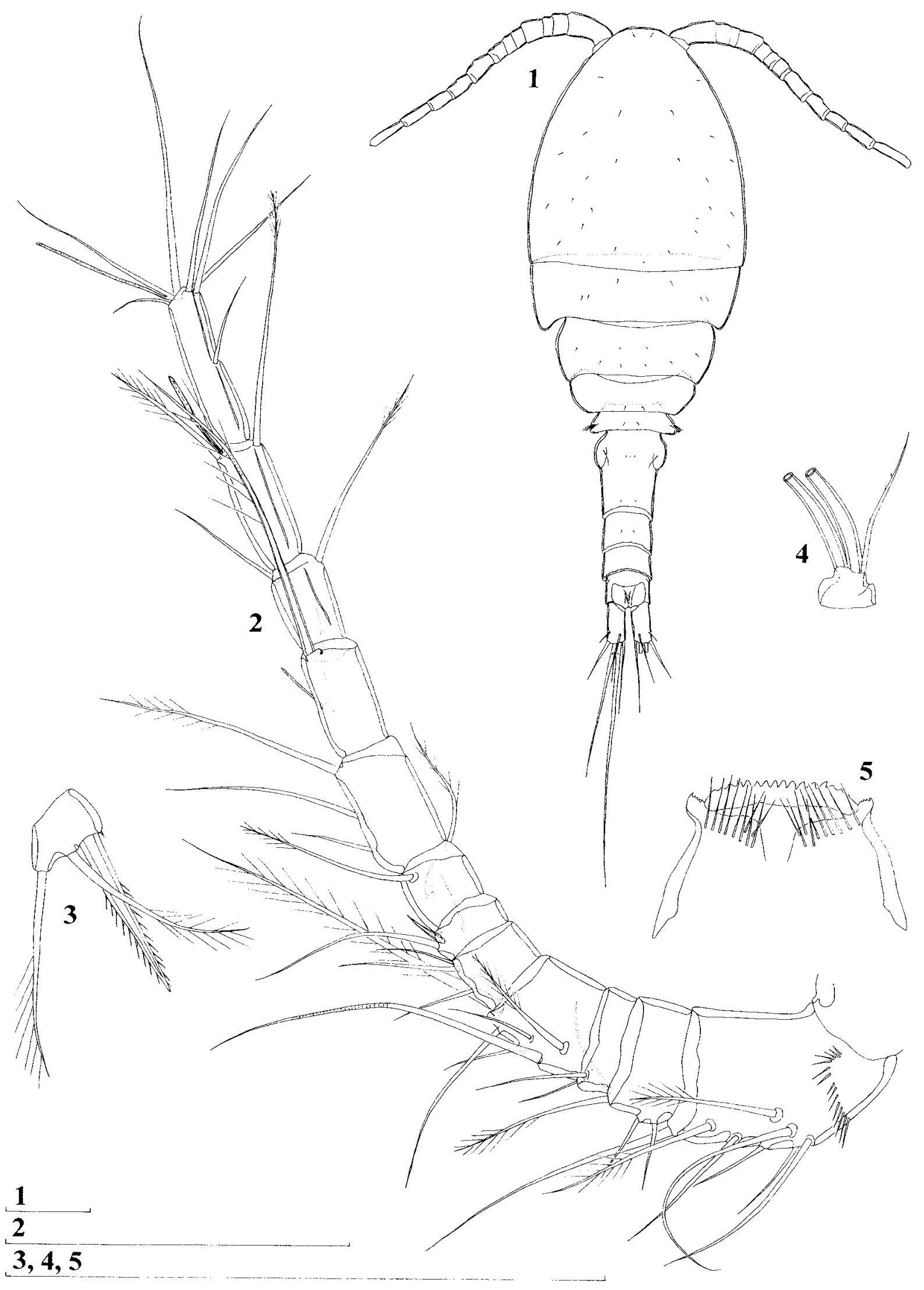

Figures 1-5 Australoeucyclops darwini sp. nov., holotype (female): 1, habitus, dorsal view; 2, antennula, anterior surface; 3, fifth leg; 4, mandibular palp; 5, labrum, ventral surface. Scales $=0.1 \mathrm{~mm}$. 

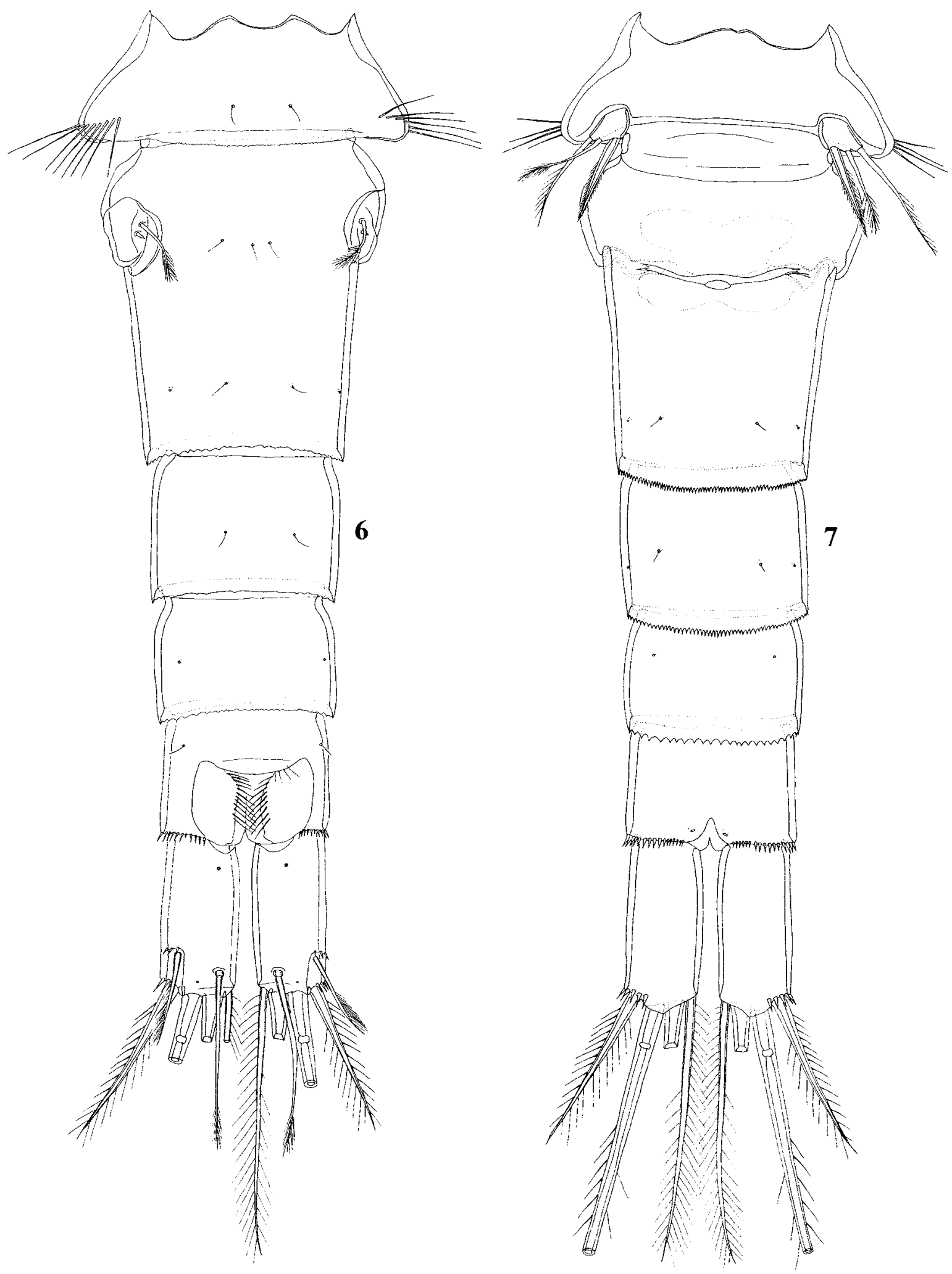

Figures 6-7 Australoeucyclops darwini sp. nov., holotype (female): 6, urosome, dorsal view; 7, urosome, ventral view. Scale $=0.1 \mathrm{~mm}$. 
(WAM C29602, C28603) dissected on 1 slide each; $1 \hat{\alpha}$ and 19 dissected together on 1 slide (TMAG G5795); 20 and 97 in alcohol (WAM C29604).

\section{Other material}

Australia: Western Australia: 1 , Margaret River region, Egerton-Warburton Soak Dam, benthos and periphyton, 9 March 2002, 34 ${ }^{\circ} 17^{\prime} 07^{\prime \prime}$, $115^{\circ} 07^{\prime} 17^{\prime \prime}$, S.M. Eberhard (WAM C28605, in alcohol); 5 ㅇ (1 ovigerous), Margaret River region, Bobs Hollow Spring, benthos and periphyton, 14 March 2002, 34 ${ }^{\circ} 03^{\prime} 50^{\prime \prime} S, 15^{\circ} 00^{\prime} 09^{\prime \prime}$ E, S.M. Eberhard (WAM C28606, in alcohol); 11 \& (2 dissected and mounted on 1 slide each), 3 $\hat{2}, 1$ copepodid, Yanchep National Park, Cabaret Cave (YN30), 1 June 1990, 31 ${ }^{\circ} 32^{\prime} 31^{\prime \prime} \mathrm{S}, 115^{\circ} 41^{\prime} 24^{\prime \prime}$ E, E.J. Jasinska (AM P.78705-P.78706); 7 ㅇ, 5 ${ }^{\lambda}, 4$ copepodids, same data except 27 January 1991, E.J. Jasinska (UWA); 6 ㅇ, 2 C, 2 copepodids, same data except 5 February 1992, E.J. Jasinska (UWA); 1 त, same data exept 29 July 1993, E.J. Jasinska (UWA); 5 ㅇ, 5 ఓ , 5 copepodids, same data except collection date unknown, E.J. Jasinska (UWA); 2 o and 2 copepodids, Yanchep National Park, Carpark Cave (YN18), collection date unknown, $31^{\circ} 33^{\prime} 08^{\prime \prime} \mathrm{S}, 115^{\circ} 41^{\prime} 08^{\prime \prime} \mathrm{E}$, E.J. Jasinska (UWA); 1 , Yanchep, Lot 51 Cave (YN555), 18 September 2003, 31 ${ }^{\circ} 34^{\prime} 31^{\prime \prime} S, 115^{\circ} 42^{\prime} 10^{\prime \prime} \mathrm{E}$, A. Storey, B. Knott (UWA); 7 ㅇ, 2 , same data except 22 September 2003, A. Storey, B. Knott (UWA); 4 ㅇ, 1 त, same data except 6 October 2004, A. Storey, B. Knott (UWA); 100 ㅇ, 14 $\hat{\text {, }}$, same data except 8 November 2005, A. Storey, B. Knott (UWA); 9 ㅇ, 8 ठे, 2 copepodids, same data except 10 October 2007, A. Storey, B. Knott and D. Tang (UWA); 3 ㅇ, Yanchep National Park, Fridge Grotto Cave (YN81), 17 July 1992, 31'31'21"S, 11540'17"E, E.J. Jasinska (UWA); 1 ㅇ, 1 ก, 6 copepodids, Yanchep National Park, Gilgie Cave (YN27), 17 March 1993, 3134'07"S, 11541'18"E, E.J. Jasinska (UWA); 7 , 4 copepodids, same data except 28 August 1994, E.J. Jasinska (UWA); 123 ㅇ (2 dissected and mounted on 1 slide each; 1 dissected and mounted together with 1 male on 1 slide (TMAG G5796)), 83 $\hat{\jmath}$ and 205 copepodids, Yanchep National Park, Yellagonga Cave (YN438), 4 October 2003, 31 ${ }^{\circ} 33^{\prime} 04^{\prime \prime}$ S, $115^{\circ} 40^{\prime} 58^{\prime \prime}$ E, A. Storey, B. Knott: (UWA); 1 ก, 1 copepodid, Yanchep National Park, Mire Bowl Cave (YN61), 17 July 1992, 31'31'32"S, $115^{\circ} 40^{\prime} 32^{\prime \prime}$, E.J. Jasinska (UWA); 1 ㅇ, same data except 18 September 2002, A. Storey (UWA); 1 , 1 $\widehat{\lambda}$, same data except 22 September 2003, A. Storey, B. Knott (UWA); 4 क (1 dissected and mounted on slide), same data except 8 November 2005, A. Storey, B. Knott (UWA); 1 , Yanchep National Park, Orpheus Cave (YN256), 17 July 1992, 3131'00"S, $115^{\circ} 40^{\prime} 10^{\prime \prime} \mathrm{E}$, E.J. Jasinska (UWA); 2 ㅇ, Yanchep National Park, Spillway Cave (YN565), 8 November 2005, 31 32'41"S, 11540'37"E, A. Storey, B. Knott (UWA); 1 ㅇ, Yanchep National Park, Twilight Cave

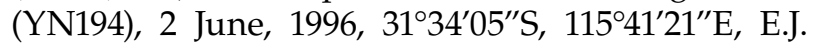

Jasinska (UWA); 3 ㅇ, 2 copepodids, same data except 27 November 1996, E.J. Jasinska (UWA); 5 ㅇ, 1 Oे, 8 copepodids, Yanchep National Park, Water Cave (YN11), 19 September 2003, 3133'02"S., $115^{\circ} 40^{\prime} 59^{\prime \prime}$ E., A. Storey, B. Knott (UWA); 4 O’, same data except 4 December 2008, A. Storey, B. Knott and D. Tang (UWA); 1 ㅇ, 1 copepodid, Bullsbrook, Mrs. King's tumulus spring, 8 May 1996, 3139'04"S., $115^{\circ} 57^{\prime} 11^{\prime \prime}$ E., E.J. Jasinska and V. English (UWA); many specimens, west of Eneabba, Beekeepers Cave (E-10), May 2007, R.A.J. Susac (DEC).

\section{Diagnosis}

Moderately large Australoeucyclops, with relatively slender habitus, one row of setules only on lateral corners of fifth pedigerous somite, long antennulae, and caudal rami less than 2.5 times as long as wide. Innermost apical seta on caudal rami 1.5 times as long as innermost one. Seminal receptacle small and butterfly-shaped. Second endopodal segment of first swimming leg with two inner setae. Apical spines on fourth leg endopod relatively robust and similar in size. Fifth leg armed with innermost robust spine and two slender, slightly longer setae.

\section{Description}

\section{Female (holotype)}

Body length, excluding caudal setae, $0.735 \mathrm{~mm}$. Habitus (Figure 1) relatively slender, with prosome/ urosome ratio 1.6 and greatest width at posterior end of cephalothorax. Body length/width ratio about 2.8; cephalothorax three times as wide as genital double-somite. Prosomal somites without pronounced lateral expansions; fifth pedigerous somite with lateral corner slightly protruded. Colour of preserved specimen yellowish. Nauplius eye not visible. Rostrum well developed, membranous, broadly rounded and furnished with two large sensilla.

Cephalothorax (Figure 1) 1.1 times as long as its greatest width; represents $40 \%$ of total body length. Surface of cephalic shield with multiple large sensilla; no other ornamentation visible. Hyaline fringe of prosomites narrow and smooth. Second and third pedigerous somites (first and second free prosomites) ornamented with few large sensilla. Fourth pedigerous somite with two large dorsal sensilla and no lateral setules. Fifth pedigerous somite with two large dorsal sensilla, smooth fringe ventrally, finely serrated fringe dorsally and row of elongate setules along each lateral protrusion (ten setules on each side; Figures 6, 7 and 9).

Genital double-somite (Figures 6, 7 and 9) slightly longer than its greatest width (ventral view), expanded anterolaterally and anteroventrally; ornamented anteriorly with three large dorsomedian sensilla and one cuticular pore on 
each side and posteriorly with two dorsal and two lateral sensilla and two lateral pores on each side. Hyaline fringe of genital double- and two subsequent somites sharply serrated ventrally and much less sharply serrated dorsally (more wavy than serrated). Copulatory pore large, ovoid; copulatory duct short, rigidly sclerotized. Seminal receptacle clearly bilobate and relatively small, representing $53 \%$ of double-somite width and 32\% of its length; anterior and posterior expansions isometric, forming characteristic butterfly shape. Parts of oviducts rigidly sclerotized. Ovipores situated dorsolaterally, covered by reduced sixth legs. Third urosomite (Figures 6 and 7) ornamented with two ventral and two dorsal sensilla and two ventrolateral cuticular pores; fourth urosomite with two median dorsolateral pores and two ventrolateral pores anteriorly. Anal somite (Figures 6 and 7) with smooth, broad and convex anal operculum, which represents $63 \%$ of somite's width; ornamented with two large sensilla dorsally and transverse row of small spinules along posterior margin. Anal sinus widely opened, ornamented with two diagonal rows of long spinules.

Caudal rami (Figures 1, 6 and 7) 2.3 times as long as wide, parallel, with space between them about one-fourth of ramus' width. Ventrodistal margin with small median protuberance, possibly representing cuticular tube pore (Figure 7). Ornamentation consisting of two dorsal cuticular pores (one proximal, one distal) and several spinules at base of lateral and outermost apical setae. Dorsal seta about 1.1 times as long as ramus, inserted at $6 / 7$ of ramus length, uniarticulate at base and plumose distally. Lateral seta arising at $3 / 4$ of ramus length, positioned somewhat dorsolaterally, uniplumose and longer than ramus width. Outermost apical seta stout, spiniform, bipinnate, about 1.1 times as long as ramus; spinules along inner margin hair-like, those along outer margin stronger. Innermost apical seta slender, plumose and about 1.5 times as long as outermost apical seta. Principal apical setae with breaking planes; inner seta about 1.8 times as long as outer seta and 0.4 times as long as body.

Antennula (Figures 1 and 2) reaching just beyond end of cephalothorax, 12-segmented, with one slender aesthetasc on ninth, eleventh and twelfth segments; setal formula: 8.4.2.6.4.2.2.3.2.2.2.7. No setae with breaking planes or articulating on basal part; one seta at anterodistal corner of sixth segment spiniform and very short. Most setae smooth, only 12 setae $(30 \%)$ plumose or pinnate at their distal end. Length ratio of antennular segments, measured along posterior margin, $1: 0.4$ $: 0.3: 0.6: 0.4: 0.3: 0.5: 1: 0.9: 0.8: 1: 1.4$. Ninth segment twice as long as wide. First segment with transverse row of large spinules; tenth, eleventh and twelfth segments each with one smooth and narrow longitudinal cuticular frill; other segments without visible ornamentation.

Antenna (Figure 13) four-segmented, comprising short coxobasis and three-segmented endopod; coxobasis somewhat longer than other three subequal segments. Coxobasis about twice as long as wide, ornamented with row of spinules along external margin, two short longitudinal rows on posterior surface, short row of stronger spinules on posterior surface near insertion of distomedial setae and three proximal, parallel rows on anterior surface; armed with two smooth setae at inner distal corner and distolateral pinnate seta representing exopod, slightly reaching beyond tip of appendage. First endopodal segment armed with one smooth seta and ornamented with longitudinal row of strong spinules along external margin and diagonal row of minute spinules on posterior surface. Second endopodal segment about 1.8 times as long as wide, ornamented with longitudinal row of spinules along external margin and armed with five medial and four distomedial smooth setae. Third endopodal segment 2.6 times as long as wide, unornamented, armed with seven apical setae; longest with several pinnules, rest smooth.

Labrum (Figure 5) trapezoidal, ornamented with 10 long, slender spinules on each side of ventral midline. Cutting edge slightly concave, with 16 small, blunt teeth between laterally produced serrated corners. No other ornamentation visible.

Mandibula (Figure 4) with small but distinct palp, armed with two very long, finely plumed setae and one short, smooth seta on distal end. Coxal gnathobase cutting edge with very strong medial teeth and outer pinnate seta, latter longer than short seta on palp.

Maxillula (Figures 10 and 11) composed of well developed praecoxa and two-segmented palp, without visible surface ornamentation. Arthrite of praecoxa with four strong, smooth apical spines of which only one distinct at base, others completely fused basally to arthrite; other seven armature elements along inner margin of arthrite, longest plumose. Palp distal segment with three apical setae (outermost strongest, longest and unipinnate; other two smooth); proximal segment armed laterally with one plumose seta and medially with two slender, pinnate setae and one robust, strongly bipinnate, spine. Palp somewhat shorter than arthrite of praecoxa.

Maxilla (Figure 16) five-segmented, but praecoxa fused to coxa on posterior surface and also partly on anterior surface. Ornamentation consisting of two short rows of spinules (proximal set larger) on anterior surface of praecoxa. Proximal endite of praecoxa elongate, robust, armed with two pinnate setae; distal endite wanting. Proximal endite of coxa 


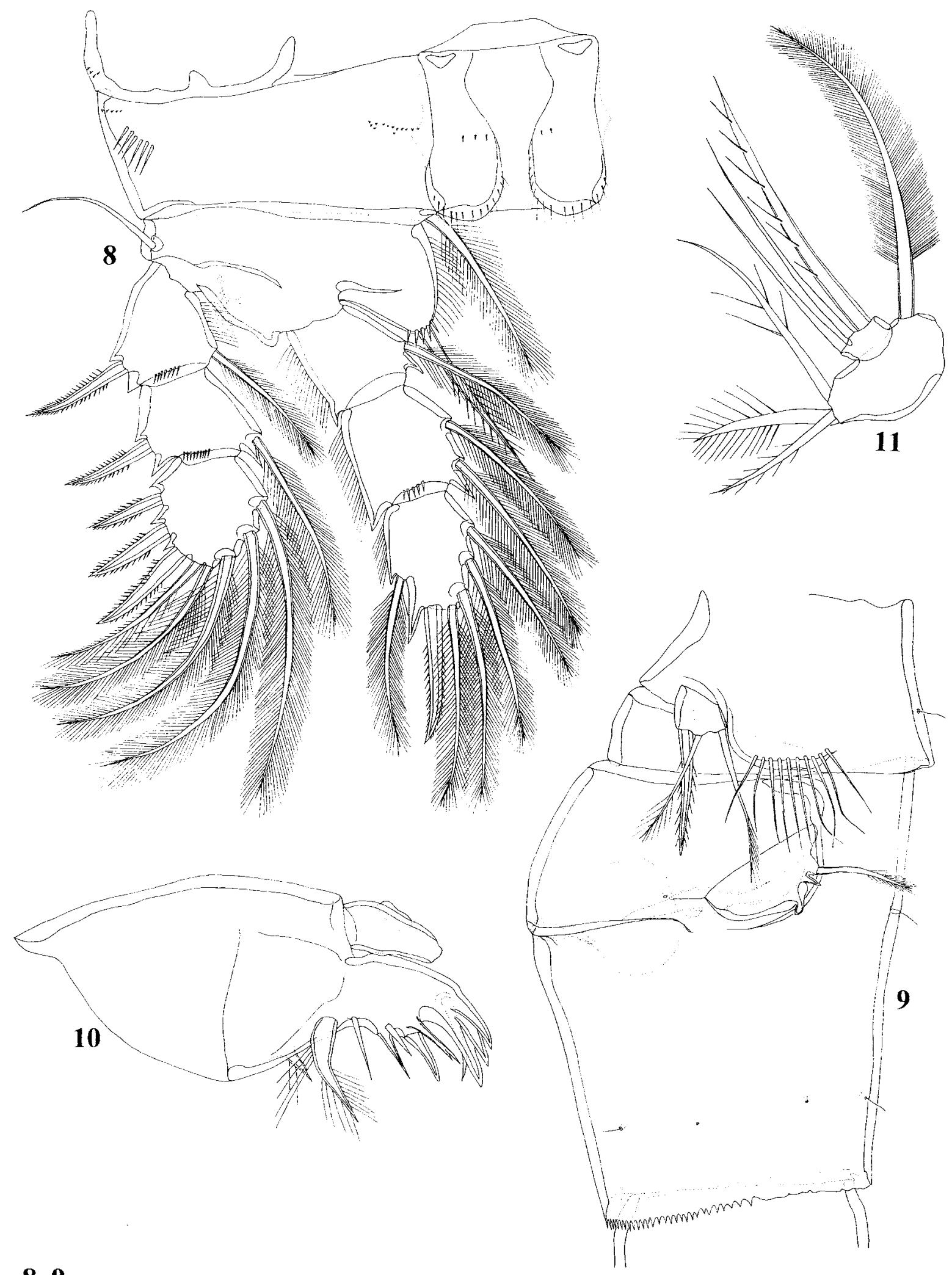

8,9

10,11

Figures 8-11 Australoeucyclops darwini sp. nov., holotype (female): 8, first swimming leg, posterior surface; 9, fifth pedigerous somite and genital double-somite, lateral view; 10, maxillula, armature on palp not figured; 11, maxillular palp. Scales $=0.1 \mathrm{~mm}$. 


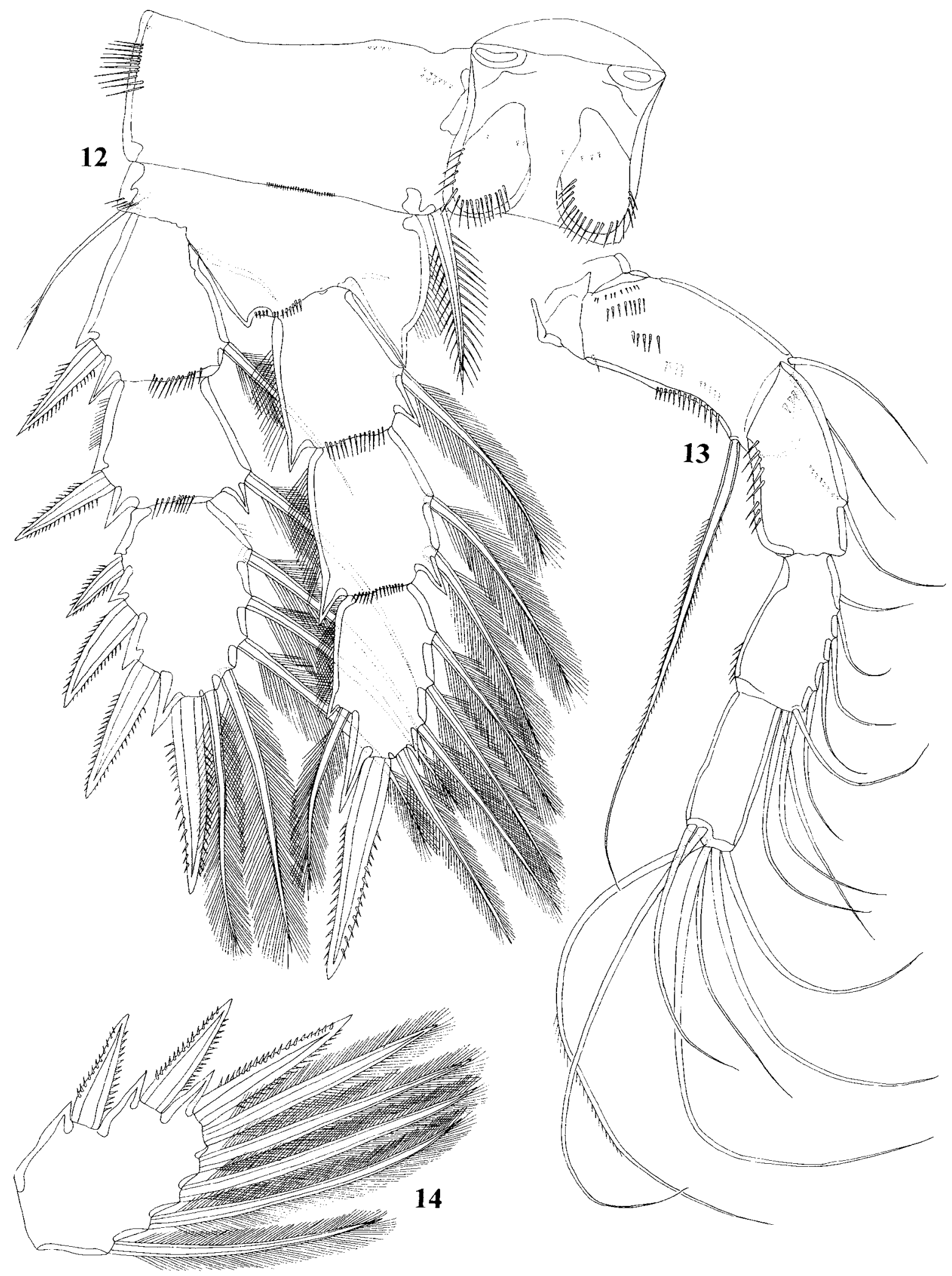

Figures 12-14 Australoeucyclops darwini sp. nov., holotype (female): 12, second swimming leg, anterior view; 13, antenna, anterior view; 14, third exopodal segment of third swimming leg. Scale $=0.1 \mathrm{~mm}$. 
hardly developed, bearing bipinnate seta; distal endite highly mobile, elongate and armed apically with one strong, pinnate seta and one slender seta. Basis with robust claw and two setae, one of them stronger, unipinnate and as long as claw; claw ornamented with longitudinal row of strong, subequal spinules along concave margin. Endopod two-segmented; proximal segment armed with two robust setae; distal segment with one robust apical seta and two slender subapical setae; all three robust setae pinnate, other two setae smooth. Longest seta on distal endopodal segment about 0.9 times as long as strong seta on basis.

Maxilliped (Figure 17) slender, four-segmented, composed of syncoxa, basis and two-segmented endopod. Syncoxa ornamented with two rows of minute spinules on anterior surface and armed with three pinnate setae; middle seta strongest and longest. Basis about as long as syncoxa and almost 2.8 times as long as wide, ornamented with arched row of strong spinules on anterior surface and two fields of minute spinules near outer margin (proximal on anterior, distal on posterior surface) and armed with two strong setae; proximal seta bipinnate and almost 1.7 times as long as distal seta. First endopodal segment ornamented with one arched row of four strong spinules and armed with one strong, unipinnate seta. Second endopodal segment very small, unornamented but armed with two smooth and one bipinnate seta; bipinnate seta completely fused basally to segment.

All swimming legs with three-segmented exopod and endopod (Figures 8, 12, 14 and 15). Armature formula of swimming legs as follows:

$\begin{array}{lcc} & \text { Exopod } & \text { Endopod } \\ \text { Leg 1 } & \text { I-1; I-1; III,2,3 } & 0-1 ; 0-2 ; 1, \mathrm{I}+1,3 \\ \text { Leg 2 } & \text { I-1; I-1; III,I+1,4 } & 0-1 ; 0-2 ; 1, \mathrm{I}+1,3 \\ \text { Leg 3 } & \text { I-1; I-1; II,I+1,4 } & 0-1 ; 0-2 ; 1, \mathrm{I}+1,3 \\ \text { Leg 4 } & \text { I-0; I-1; II,I+1,4 } & 0-1 ; 0-2 ; 1, \mathrm{II}, 2\end{array}$

Third exopodal segment spine formula 3.4.3.3. Intercoxal sclerites with rounded protrusion at each side of distal margin, ornamented with arched rows of spinules on both anterior and posterior surfaces laterally and distally, as well as several minute spinules at middle on posterior surface. All coxae ornamented with multiple rows of spinules and armed with one pinnate seta at inner distal corner; this seta very robust, almost spiniform, in fourth leg (Figure 15). Spine inserted at inner, protruded corner of basis of first leg reaching third endopodal segment (Figure 8). All setae slender and plumose; outer apical seta on third exopodal segment of first leg with long pinnules along inner margin and short ones along outer margin (Figure 8). First two segments of both rami of each leg with short row of spinules along distal margin, usually on both sides. Third endopodal segment of fourth swimming leg about 1.7 times as long as wide; both spines very strong, nearly subequal in length (outer spine slightly longer than inner spine) and about 1.3 times as long as segment (Figure 15).

Fifth leg (Figure 3) represented by simple, quadrate (or slightly trapeziform), small cuticular plate, with single minute spinule on inner distal corner and armed with three elements, all inserted on same plane and each on own small protuberance. Outermost seta (probably ancestral basal one) slender, unipinnate along outer margin, about 3.8 times as long as segment. Middle seta also slender, plumose at distal end, about as long as outermost one. Innermost spine very strong, about 0.8 times as long as middle seta and three times as long as segment.

Sixth leg (Figure 9) distinct, represented by semicircular cuticular plate, armed with two nearly subequal, minute smooth spines and one longer bipinnate seta; median spine distinct, other one completely fused to leg.

\section{Male (allotype)}

Body length excluding caudal setae, 0.612 $\mathrm{mm}$. Habitus (Figure 20) much more slender than in female, with prosome/urosome ratio 1.6 and greatest width attained at posterior end of cephalothorax. Body length/width ratio about 3.1; cephalothorax about three times as wide as genital somite.

Cephalothorax (Figure 20) 1.2 times as long as greatest width (from dorsal view). Ornamentation of prosomites, colour and nauplius eye similar to those of female. Fifth pedigerous somite (Figures 20 and 23) with less protruded lateral corners than in female and lacking elongated setules on lateral margins. Hyaline fringe of fifth pedigerous somite smooth; that of genital somite sharply serrated dorsally; that of other urosomites (except anal one) sharply serrated both dorsally and ventrally (Figure 23).

Genital somite without any visible surface ornamentation; third urosomite with pair of ventral sensilla; fourth and fifth urosomites each with two ventral cuticular pores (Figure 23). Anal somite with smooth, concave and very broad anal operculum, which represents $65 \%$ of somite's width; ornamented with two dorsal sensilla, transverse row of spinules along posteroventral margin and two ventral cuticular pores. Anal sinus wide, ornamented with two diagonal rows of minute spinules.

Caudal rami (Figure 23) about 1.8 times as long as wide, parallel, with very narrow space left between them. Armature and ornamentation similar to female, except innermost apical seta somewhat longer. 
Antennula (Figure 21) of almost equal length as cephalothorax, 16-segmented, digeniculate, with geniculations between ninth and tenth and between fourteenth and fifteenth segments. First segment with short, diagonal row of spinules; other segments without ornamentation. Fourteenth and fifteenth segments with characteristic cuticular structures (geniculation blades). Sensory cylinder formula: 2.1.1.2.0.1.0.0.1.0.0.0.0.0.0.1. Sensory cylinder on the sixteenth segment slender and smooth (aesthetasc); all others apically setose (sensory clubs). Setal formula: 6.3.1.1.1.1.1.2.2.2.3.1.1.0.2.11. Setae on eleventh, twelfth, thirteenth and fifteenth segments characteristically modified, spiniform. Only two spiniform setae (one on eleventh and one on thirteenth segment), one slender seta on second segment and one on fifteenth segment pinnate at their distal end; only seven setae (one on fifteenth and six on sixteenth segment) articulating on basal part.

Antenna, labrum, mandibula, maxillula, maxilla, maxilliped and swimming legs (Figure 22) similar to female.

Fifth leg (Figures 23 and 24) also similar to female, except innermost spine and middle seta slightly shorter.

Sixth leg (Figures 23 and 25) represented by distinct large plate, armed with one spine and two pinnate setae and ornamented proximally with single cuticular pore. Innermost spine about as long as spine on fifth leg and slightly longer than middle seta. Outermost seta about 1.5 times as long as spine and 1.8 times as long as middle seta.

\section{Variability}

Although numerous female and male specimens were dissected and examined, almost no variability worth reporting was discovered. Body length of females ranges from $0.654 \mathrm{~mm}$ to $0.785 \mathrm{~mm}(0.737$ $\mathrm{mm}$ average; $\mathrm{n}=17$ ), while in males it ranges from $0.600 \mathrm{~mm}$ to $0.665 \mathrm{~mm}$ (0.632 $\mathrm{mm}$ average; $\mathrm{n}=6$ ). Apical spines on the third endopodal segment of the fourth swimming leg are generally subequal, with usually the outer one being slightly longer (Figures 15, 18 and 22), but sometimes the inner spine can be slightly longer (Figure 19). Egg-sacs of ovigerous females contain between four and six eggs. Very small differences in the finest ornamentation of the swimming legs and mouthparts were also observed.

\section{Etymology}

The species is named in honour of the late Charles Darwin, as a celebration of the $200^{\text {th }}$ anniversary of his birth and the $150^{\text {th }}$ anniversary of the publication of his famous book "The origin of species by means of natural selection, or the preservation of favoured races in the struggle for life". The name is a noun in the genitive singular.

\section{DISCUSSION}

The new species fits nicely into the generic diagnosis of Australoeucyclops by having a slender habitus, 12-segmented female antennula, inner corner of the basis of second, third and fourth swimming legs produced into a large acute process, absence of an inner seta on the proximal exopodal segment of the fourth leg, spine formula of the third exopodal segments of the swimming legs 3.4.3.3, and 1-segmented fifth leg with 3 apical elements (innermost robust spine and two setae) all inserted on the same plane. The genus, as defined by Karanovic (2006), included five species. Australoeucyclops karaytugi Karanovic, 2006 was described from Weeli Wolli Spring in the Pilbara region of Western Australia and designated as the type species, but Karanovic also formally transferred to this genus four other members from the genera Eucyclops Claus, 1893 and Paracyclops Claus, 1893. Australoeucyclops eucyclopoides (Kiefer, 1929) was originally described as Paracyclops eucyclopoides from Lombok (near Java) by Kiefer (1929), and later reported and redescribed from Sumatra, Java and Bali (Heberer and Kiefer 1932; Kiefer 1933). Heberer and Kiefer (1932) and Kiefer (1933) noted mixed characters of Paracyclops and Eucyclops in this species (a factor reflected also in Kiefer's (1929) choice of specific name), but it was not until much later (Kiefer 1969) that its spine formula was corrected (3.4.3.3 instead of 3.4.4.3). The second species was described from South Australia by Lindberg (1948), as Eucyclops linderi, and included in his list of Australian cyclopoids (Lindberg 1953). Morton (1990) formally transferred this species into the genus Paracyclops, which reflected its unsettled generic position. The third species formally transferred into the genus Australoeucyclops was described from New South Wales as Paracyclops timmsi by Kiefer (1969), who also noted its very close relationship with $P$. eucyclopoides but failed to recognise its similarity with Lindberg's Eucyclops linderi. Finally, Lewis (1974) described Paracyclops waiariki from New Zealand and noted that "it does not conform precisely to the generic description". This species was redescribed in detail by Karaytug and Boxshall (1998a), although without any mention of its questionable position in the genus Paracyclops.

Unfortunately, only A. karaytugi and A. waiariki (Lewis, 1974) are described (or redescribed) in sufficient detail to allow a proper comparison with A. darwini sp. nov., while A. eucyclopoides, A. linderi (Lindberg, 1948) and A. timmsi (Kiefer, 1969) are only partly described and many characters are unknown. This, and the fact that $A$. timmsi and $A$. linderi are known only after females, precluded 


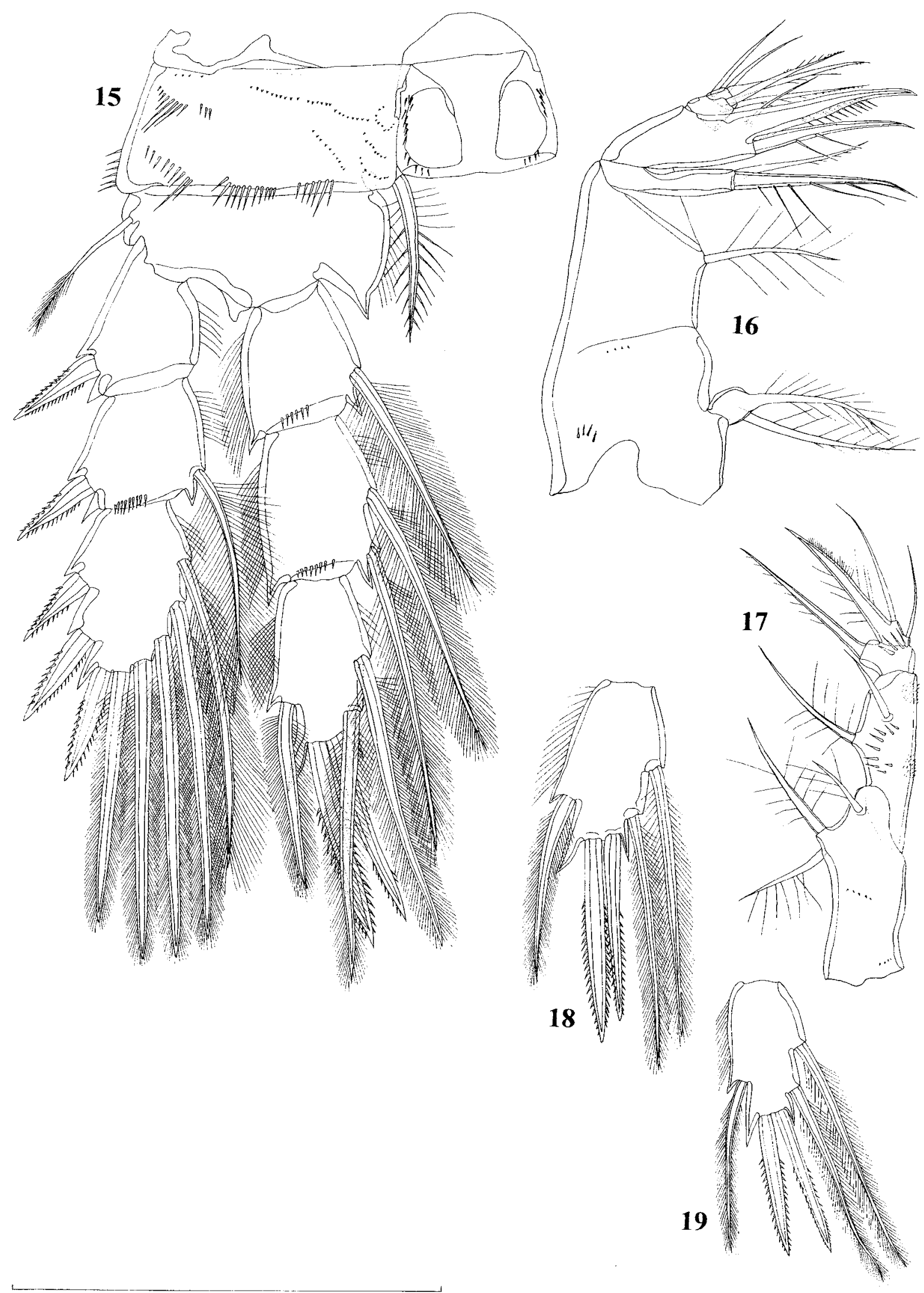

Figures 15-19 Australoeucyclops darwini sp. nov., 15-17, holotype (female); 18, paratype female (0.726 mm); 19, paratype male $(0.619 \mathrm{~mm}): 15$, fourth swimming leg, posterior view; 16 , maxilla, anterior view; 17 , maxilliped, anterior view; 18, third endopodal segment of fourth swimming leg; 19, third endopodal segment of fourth swimming leg. Scale $=0.1 \mathrm{~mm}$. 


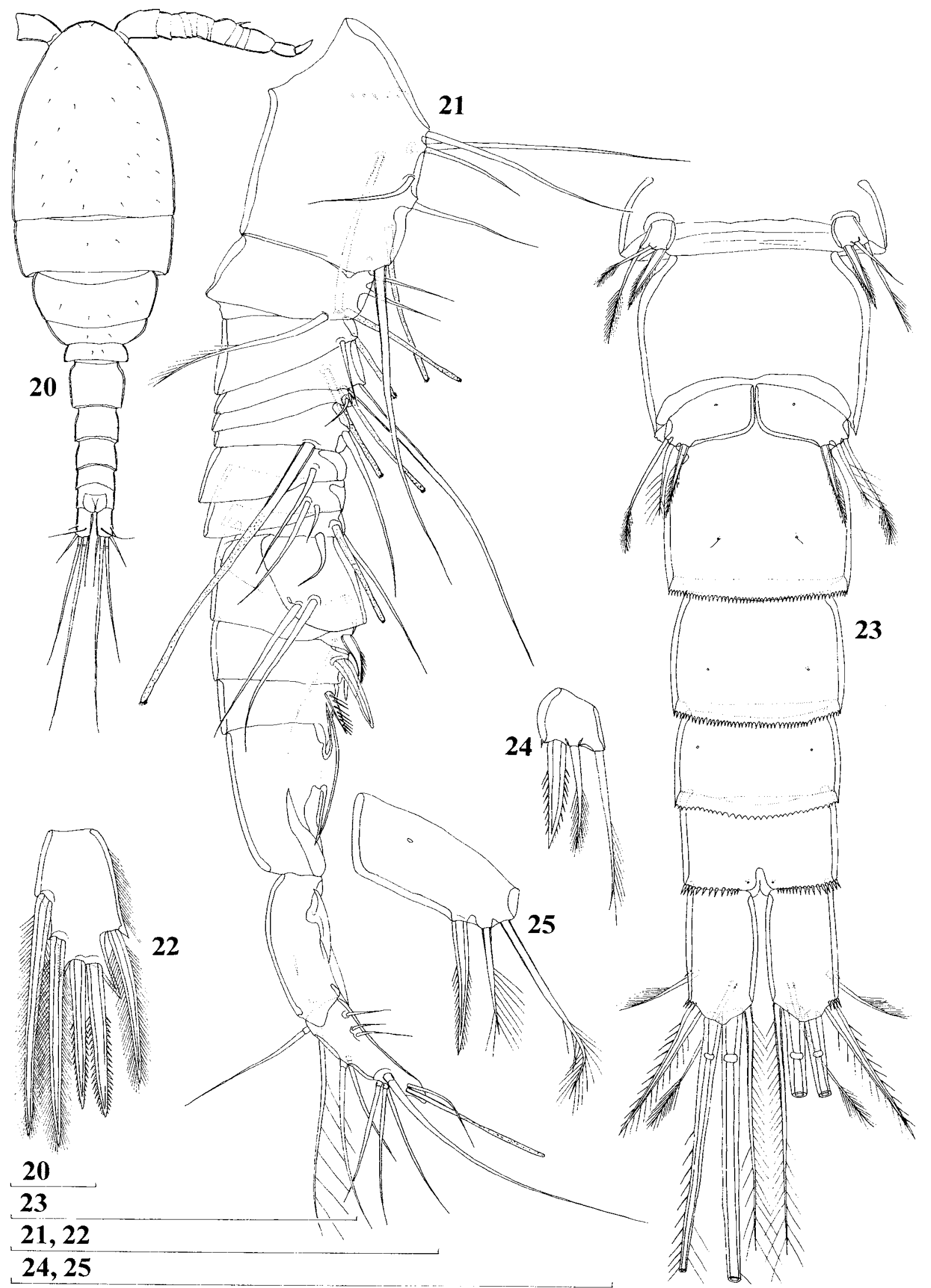

Figures 20-25 Australoeucyclops darwini sp. nov., allotype (male): 20, habitus, dorsal view; 21, antennula, posterior surface; 22, third endopodal segment of fourth swmming leg; 23, urosome, ventral view; 24, fifth leg; 25, sixth leg. Scales $=0.1 \mathrm{~mm}$. 
us from analysing the phylogenetic relationships of Australoeucyclops. However, the new species differs from all its congeners by its subequal apical spines on the fourth leg endopod (Figures $15,18,19$ and 22) and relatively short caudal rami (Figures 6, 7 and 23), but can be distinguished further by a number of other characters. It differs from the Indonesian A. eucyclopoides also by a much more robust and longer middle seta on the fifth leg (which is delicate and shorter than the spine in A. eucyclopoides), more elongated third endopodal segment of the fourth leg and smaller and differently shaped seminal receptacle (which has an oval anterior part in A. eucyclopoides). Australoeucyclops linderi differs from all other congeners by the relative size of the inner apical spine of the fourth leg endopod, which is much shorter than the outer apical one. This South Australian species seems to differ from $A$. darwini also by the longer caudal rami and absence of lateral setules on the fifth pedigerous somite (as far as we can tell from Lindberg's (1948) drawings) and outer apical spiniform seta on the third endopodal segment of the third leg. The New South Wales $A$. timmsi differs from $A$. darwini by having a relatively shorter spine on the fifth leg, much larger seminal receptacle, much longer caudal rami (actually twice as long), much longer inner apical spine on the distal endopodal segment of the fourth leg (the inner spine is twice as long as the outer one) and setules on the lateral corners of the fourth pedigerous somite. The last three differences are also true for the New Zealand A. waiariki, which can be distinguished additionally from $A$. darwini by its highly ornate caudal rami, shorter antennulae and antennae, as well as a longer inner basal spine on the first leg. Finally, the Western Australian A. karaytugi can be distinguished from $A$. darwini by the following characters: a more slender habitus; fourth pedigerous somite with lateral setules (absent in the new species); fifth pedigerous somite with two parallel rows of lateral setules (only one in the new species); longer caudal rami $(1 / \mathrm{w}$ index 3.8 vs. 2.3); innermost apical seta on caudal rami shorter than outermost apical one (longer in the new species); shorter antennula and antenna; second endopodal segment of first swimming leg with only one inner seta (two in the new species); and inner apical spine on the third endopodal segment of the fourth leg 2.5 times as long as outer apical one (of about the same length in the new species). Below is the key to species to aid in their identification.

\section{KEY TO SPECIES OF AUSTRALOEUCYCLOPS}

1. Apical spines on third endopodal segment of fourth leg very different in size........................ 2

Spines subequal ..................... A. darwini sp. nov.

2. Inner apical spine on third leg endopod significantly longer than outer spine ................ 3

Inner spine much shorter than outer spine A. linderi (Lindberg, 1948)

3. Innermost apical seta on caudal rami longer than outermost one. . .4

Innermost seta shorter A. karaytugi Karanovic, 2006

4. Caudal rami with smooth surface 5

Rami with numerous minute spinules A. waiariki (Lewis, 1974)

5. Spine on fifth leg about as long as outer seta....... A. eucyclopoides (Kiefer, 1929)

Spine much shorter ..A. timmsi (Kiefer, 1969)

As previously mentioned, the new species is described from three disjunct populations from the Margaret River region, Gnangara Mound region and Eneabba, but we expect that further investigations of both surface and subterranean environments in this part of Western Australia will slowly fill the gaps in its known distribution. All these localities are situated in an area of Quaternary dune deposits within the Swan Coastal Plain (Davidson 1995). Further, the cave sites occur near the coast in areas consisting of an aeolian calcarenite layer overlying quartz sands of mid-Pleistocene age (Kendrick et al. 1991). These sampling sites are probably well interconnected, as we did not find any substantial morphological variability between these disjunct populations. However, more interesting is the habitat choice of these three populations. The Margaret River population was found only in surface water habitats (two springs and one dam) despite a thorough survey of subterranean habitats in that area (Eberhard 2004; Karanovic 2005; although most results regarding stygal harpacticoids are still awaiting publication). The two northern populations (Gnangara Mound and Eneabba), on the other hand, were found almost entirely in caves. This habitat shift is probably a consequence of the psychrophilic ecology of this species, which in warmer northern areas probably seeks cooler environments such as that afforded by subterranean waters; this trait is not uncommon in copepods. For example, the Holarctic Diacyclops crassicaudis (Sars, 1863) is a stygobiont 
in Southern Europe, stygophile in Central Europe and stygoxene in Northern Europe (Rylov 1948; Dussart 1969; Monchenko 1974). It is obviously a glacial relict in Southern Europe (Karanovic, unpublished $\mathrm{PhD}$ thesis). However, in Australia the main driving force for habitat shifts seems to be aridity associated with global climate changes in the same period (Karanovic 2004), and we believe this is also the case with $A$. darwini. This scenario is consistent with the disjunct distribution patterns of many Australian copepods (Karanovic 2006, 2008) and may also explain the distribution of the Australoeucyclops species in Australia. As we noted above, the four Australian representatives are present in New South Wales, South Australia, south-western Western Australia and northwestern Western Australia (Pilbara region), but the genus is absent from the well surveyed Murchison region, which lays between the Pilbara and south-western Western Australia. Karanovic (2006) proposed a "pulsating desert hypothesis" as a novel dynamic model that may explain some of the incredible differences in stygofaunas (not just copepods) of these two neighbouring Western Australian regions. It is interesting to note that these distribution patterns are also nicely reflected in the marine interstitial medium (Karanovic 2008), which emphasizes the importance of looking at small-scale patterns when inferring Gondwanan biogeography and challenges assumptions of monophyly of large continental blocks (Giribet and Edgecombe 2006).

The order Cyclopoida Rafinesque, 1815 today has around 1360 valid species, classified into 204 genera and 18 families (Karanovic 2008). The recently described family Abrsidae Karanovic, 2008 has only one species in the Australian marine interstitial. The largest family is Cyclopidae Rafinesque, 1815, with more than 780 species in 60 genera (Boxshall and Halsey 2004), mostly free-living in freshwater and with some representatives in coastal and brackish waters. It is currently subdivided into four subfamilies: Cyclopinae Rafinesque, 1915; Eucyclopinae Kiefer, 1927; Halicyclopinae Kiefer, 1927; and Euryteinae Monchenko, 1975. The genus Australoeucyclops undoubtedly belongs to the subfamily Eucyclopinae, which presently encompasses about 187 species and subspecies, that are mostly benthic in freshwater habitats and classified into 11 valid genera (Dussart and Defaye 1985, 2006; Pospisil and Stoch 1997; Boxshall and Halsey 2004): Afrocyclops Sars, 1927; Australoeucyclops; Austriocyclops Kiefer, 1964; Ectocyclops Brady, 1904; Eucyclops; Homocyclops Forbes, 1897; Macrocyclops Claus, 1893; Ochridacyclops Kiefer, 1937; Paracyclops; Thaumasiocyclops Kiefer, 1930; and Tropocyclops Kiefer, 1927.
Among other characters, Kiefer (1927) defined this subfamily by the presence of three armature elements on the terminal (or only) segment of the fifth leg. However, he (Kiefer 1930, 1933) recognised Eucyclops teras (Graeter, 1907) (later redescribed and transferred into a separate subgenus Stygocyclops by Pleşa (1971)) and Thaumasiocyclops insulanus Kiefer, 1930 also as members of the subfamily Eucyclopinae, although they have only two armature elements on the fifth leg. Heberer and Kiefer (1932) even reported one aberrant female of Eucyclops serrulatus (Fishcher, 1851) with only two armature elements on the fifth leg. There are only three other species of Eucyclopinae with fewer than three armature elements on the fifth leg. The first one is Austriocyclops vindobonae Kiefer, 1964, which was rediscovered, redescribed and transferred from Cyclopinae to Eucyclopinae by Pospisil and Stoch (1997). It has a completely reduced fifth leg, with only one or two setae as its remnants. It should be said that the genus Ectocyclops also has a completely reduced fifth leg, but in this genus all 17 species and subspecies have retained three armature elements. Tropocyclops jamaicensis Reid and Janetzky, 1996 constitutes the fifth known case (including the earlier mentioned aberrant specimen of Eucyclops serrulatus) of reduction of the number of fifth leg armature elements in Eucyclopinae. It was described from phytotelmata in leaf axils of Jamaican bromeliads (Reid and Janetzky 1996), but according to Karanovic (2006) it represents a separate genus. Finally, Defaye (2007) described Tropocyclops matanoensis Defaye, 2007 with only two elements on the fifth leg, from the deep waters of the ancient Lake Matano, Indonesia. The genera Thaumasiocyclops, Austriocyclops and the subgenus Stygocyclops are still monospecific (Dussart and Defaye 2006).

Australoeucyclops has a 1-segmented fifth leg with three armature elements (innermost spine and two setae), like the genera Afrocyclops, Eucyclops, Ochridacyclops, Paracyclops and Tropocyclops. Afrocyclops is an endemic African (including Madagascar) genus (only A. gibsoni abbreviatus (Kiefer, 1933) is found additionally in Java and Bali). It is morphologically most similar to Eucyclops but clearly distinguished by the position of a lateral seta on the terminal segment of the female antennula, absence of sensory clubs on the male antennula, an exceptionally long spine on the sixth leg in male, a smooth outer margin of the caudal rami and the spine formula of the swimming legs 2(3).3.3.3 (see Einsle 1971). Tropocyclops is the only other genus in the subfamily lacking the sensory clubs on the male antennula (they have smooth sensory cylinders (aesthetascs), like in Cyclopinae); it also has a very characteristic seminal receptacle and an exceptionally long inner apical spine on the third endopodal segment of the fourth 
swimming leg. Ochridacyclops was described from a freshwater sponge from Lake Ohrid (Macedonia) by Kiefer (1937). Petkovski (1954) described a separate subspecies from another sponge from Lake Prespa (also Macedonia), and another new species was later described from streams in Kwangtung (China) by Shen and Tai (1964) (see also Shen et al. 1979). Two species described from Japan by Karaytug et al. (1996) and Ishida (2002) in the genus Ochridacyclops are, according to Karanovic (2006), obvious members of Eucyclops, from which the former can be distinguished by the 11-segmented female antennulae. Three recently described species of Ochridacyclops from Korea, Kenya and Nepal (see Lee et al. 2004; Tomikawa et al. 2005) widen the generic diagnosis even further and place this group in urgent need of revision. The genus Paracyclops was recently partly revised (Karaytug and Boxshall 1998a, b) and studied extensively (Karaytug and Boxshall 1996, 1998c, 1999; Karaytug et al. 1998; Karaytug 1999). Although Karaytug and Boxshall (1998b) redescribed the type species and designated a neotype, they failed to revise the generic diagnosis and its relationships with the other Eucyclopinae. In fact, not a single species was synonymised for the first time in that revision nor was its taxonomic status within the genus questioned. Consequently, species described in other genera (like Eucyclops linderi) were not discussed or transferred into Paracyclops. The genus Australoeucyclops is probably most closely related to the genera Eucyclops and Paracyclops, but is well defined by its slender habitus, caudal rami shape, 12-segmented antennulae, spine formula, absence of inner seta on the first exopodal segment of the fourth leg and its fifth leg shape.

The genus Macrocyclops is the only one in the subfamily with a two-segmented fifth leg (Karaytug 1999). Its six valid species (Dussart and Defaye 2006) have an isolated position within the Eucyclopinae also because of the nature of the outermost armature element on the apical segment of the fifth leg, which is on the other hand similar to that in the monospecific genus Homocyclops. The latter genus differs from Macrocyclops essentially only by the reduced segmentation of the fifth leg (proximal segment completely lost), while the armature of the distal segment (the only segment in Homocyclops) is the same and consists of an innermost subapical spine, middle apical seta and outermost subapical spine. All other Eucylopinae genera have the outermost armature element as a slender seta, which probably represents the outer basal seta and is, therefore, homologous with the outer seta on the proximal segment rather than the outermost spine on the distal segment of Macrocyclops. However, the alternative interpretation that the outermost slender armature element of all other Eucyclopinae genera is homologous to the outer distal spine of Macrocyclops-Homocyclops, and that all of them have lost the outer basal seta, cannot be completely ruled out and will require a comprehensive phylogenetic analysis to resolve this problem. The genera Macrocyclops and Homocyclops also share a 17-segmented female antennula, while other Eucyclopinae genera have this appendage at most 12-segmented. These plesiomorphic characters place these two genera as a sister-group to all other Eucyclopinae, but also to Cyclopinae members, which have a 17-segmented antennula in more primitive genera and have preserved the outer basal seta on the fifth leg even when both segments are completely fused to the somite and, on the other hand, have lost the outermost subapical spine (just as other members of Eucyclopinae). The fact that the proximal segment (and outer basal seta) is lost on the fifth leg of the genus Homocyclops shows that this cyclopoid has followed a completely different evolutionary path. The genus Macrocyclops is only probably separated from Homocyclops by a single evolutionary event and it looks like it can be very similar to its ancestor (if it is not its ancestor). Non-expressed basis of the fifth leg is certainly a regressive trait and it is questionable if Homocyclops deserves a separate generic status.

\section{REFERENCES}

Boxshall, G.A. and Halsey, S.H. (2004). An Introduction to Copepod Diversity. The Ray Society: London.

Davidson, W.A. (1995). Hydrogeology and Groundwater Resources of the Perth Region, Western Australia. Western Australia Geological Survey, Bulletin 142: 1-257.

Defaye, D. (2007). A new Tropocyclops (Copepoda, Cyclopidae) from Lake Matano, Indonesia. Zootaxa 1541: 17-29.

Dussart, B. (1969). Les Copépodes des eaux continentales d'Europe Occidentale, 2. Cyclopoïdes et Biologie. N. Boubée \& Cie: Paris.

Dussart, B. and Defaye, D. (1985). Répertoire Mondial des Copépodes Cyclopoïdes. Centre National de la Recherche Scientifique: Bordeaux.

Dussart, B. and Defaye, D. (2006). World Directory of Crustacea Copepoda of Inland Waters. II - Cyclopiformes. Backhuys Publishers: Leiden.

Eberhard, S.M. (2004). Ecology and Hydrogeology of a Threatened Groundwater-dependent Ecosystem: the Jewel Cave Karst System in Western Australia. Ph.D. Thesis, Murdoch University.

Einsle, U. (1971). Freilebende Copepoden. Resultats Scientifiques de l'Exploration Hydrobiologique du Basin du Lac Bangweolo et du Luapula 13: 1-74.

Giribet, G. and Edgecombe, G.D. (2006). The importance of looking at small-scale patterns when inferring Gondwanan biogeography: a case study of the centipede Paralamyctes (Chilopoda, Lithobiomorpha, Henicopidae). Biological Journal of the Linnean Society 89: 65-78. 
Heberer, G. and Kiefer, F. (1932). Zur Kenntnis der Copepodenfauna der Sunda Inseln. Archiv für Naturgeschichte Berlin 1: 225-274.

Humes, A.G. and Gooding, R.U. (1964). A method for studying the external anatomy of copepods. Crustaceana 6: 238-240.

Humphreys, W.F. (2000). Background and glossary. (pp. 3-14). In: Wilkens, H., Culver, D.C. and Humphreys, W.F. (eds). Ecosystems of the World, 30: Subterranean Ecosystems. Elsevier: Amsterdam.

Huys, R. and Boxshall, G.A. (1991). Copepod Evolution. The Ray Society: London.

International Commission on Zoological Nomenclature (1999). International Code of Zoological Nomenclature, fourth edition. International Trust for Zoological Nomenclature: London.

Ishida, T. (2002). The second species of Ochridacyclops Kiefer, 1937 (Copepoda, Cyclopoida) from Japan. Biogeography 4: 19-23.

Jasinska, E.J. and Knott, B. (2000). Root-driven faunas in cave waters. (pp. 287-307). In: Wilkens, H., Culver, D.C. and Humphreys, W.F. (eds.), Ecosystems of the world: Subterranean ecosystems. Elsevier: Amsterdam

Karanovic, T. (2004). Subterranean Copepoda from Arid Western Australia. Crustaceana Monographs 3, Brill: Leiden.

Karanovic, T. (2005). Two new subterranean Parastenocarididae (Crustacea, Copepoda, Harpacticoida) from Western Australia. Records of the Western Australian Museum 22: 353-374.

Karanovic, T. (2006). Subterranean copepods (Crustacea, Copepoda) from the Pilbara region in Western Australia. Records of the Western Australian Museum Supplement 70: 1-239.

Karanovic, T. (2008). Marine Interstitial Poecilostomatoida and Cyclopoida (Copepoda) of Australia. Crustaceana Monographs 9, Brill: Leiden.

Karaytug, S. (1999). Copepods: Cyclopoida, Genera Paracyclops, Ochridacyclops and key to the Eucyclopinae. Guides to the Identification of the Microinvertebrates of the Continental Waters of the World, 14, Backhuys Publishers: Leiden.

Karaytug, S. and Boxshall, G.A. (1996). The life cycle of Paracyclops fimbriatus (Fischer, 1853) (Copepoda, Cyclopoida). Bulletin of the Natural History Museum London, Zoology 62: 41-70.

Karaytug, S. and Boxshall, G.A. (1998a). Partial revision of Paracyclops Claus, 1893 (Copepoda, Cyclopoida, Cyclopidae) with descriptions of four new species. Bulletin of the Natural History Museum London, Zoology 64: 111-205.

Karaytug, S. and Boxshall, G.A. (1998b). The Paracyclops fimbriatus-complex (Copepoda, Cyclopoida): a revision. Zoosystema 20: 563-602.

Karaytug, S. and Boxshall, G.A. (1998c). The female antennules of Paracyclops (Cyclopoida: Cyclopidae): their significance for systematics. Journal of Marine Systems 15: 397-400.

Karaytug, S. and Boxshall, G.A. (1999). Antennules of the male of Paracyclops (Copepoda): functional significance and their importance in systematics. Journal of Crustacean Biology 19: 371-379.
Karaytug, S., Boxshall, G.A. and Ishida, T. (1996). A new species of Ochridacyclops (Kiefer, 1937) (Copepoda, Cyclopoida) from Japan. Hydrobiologia 332: 111-117.

Karaytug, S., Defaye, D. and Boxshall, G.A. (1998). Two new species of Paracyclops (Copepoda: Cyclopoida, Cyclopidae) from Africa. Hydrobiologia 382: 119-136.

Kendrick, G.W., Wyrwoll, K.H. and Szabo, B.J. (1991). Pliocene-Pleistocene coastal events and history along the western margin of Australia. Quaternary Science Reviews 10: 419-439.

Kiefer, F. (1927). Versuch eines Systems der Cyclopiden. Zoologischer Anzeiger 73: 302-308.

Kiefer, F. (1929). Neue Ruderfußkrebse von den SundaInseln. Zoologischer Anzeiger 84: 46-49.

Kiefer, F. (1930). Neue Ruderfußkrebse von den SundaInseln. Zoologischer Anzeiger 86: 185-189.

Kiefer, F. (1933). Die freilebenden Copepoden der Binnengewässer von Insulinde. Archiv für Hydrobiologie supplement 12: 519-621.

Kiefer, F. (1937). Ein neuer Cyclopide (Crust. Copepoda) aus dem Ochridasee. Zoologischer Anzeiger 120: 137143.

Kiefer, F. (1969). Eine neue Paracyclops-Art (Crustacea Copepoda) aus Australien. Zoologischer Anzeiger 182: 91-94.

Lee, J.M., Jeon, J.M. and Chang C.-Y. (2004). Two semisubterranean copepods from Korea. Korean Journal of Biological Sciences 8: 145-154.

Lewis, M.H. (1974). Paracyclops waiariki n.sp. (Copepoda: Cyclopoida) from thermal waters in Rotorua. New Zealand Journal of Marine and Freshwater Research 8: 275-281.

Lindberg, K. (1948). Deux Cyclopides (Crustacés Copépodes) nouveaux de l'Australie. Bulletin de la Societe Zoologique de France 73: 71-76.

Lindberg, K. (1953). Cyclopides (Crustacés Copépodes) de l'Australia. Lunds Universitets Årsskrift (n.f.) 49: 1-8.

Monchenko, V.I. (1974). Schelepnoroti Ciklopopodibni Ciklopi (Cyclopidae). Fauna Ukraïni 27(3): pp. 1-452. (Kiev)

Morton, D.W. (1990). Revision of the Australian Cyclopidae (Copepoda: Cyclopoida), II. Eucyclops Claus and Ectocyclops Brady. Australian Journal of Marine and Freshwater Research 41: 657-675.

Petkovski, T. (1954). Beitrag zur Kenntnis der jugoslavischen Cyclopiden. Acta Musei Macedonici Scientiarum Naturalium 12(4): 1-31.

Pleşa, C. (1971). Contribution à la connaissance des Cyclopides (Crustacea, Copepoda) des grottes et des eaux interstitielles de Suisse. Revue Suisse de Zoologie 78: 833-850.

Pospisil, P. and Stoch, F. (1997). Rediscovery and redescription of Austriocyclops vindobonae Kiefer, 1964 (Copepoda, Cyclopoida) with remarks on the subfamily Eucyclopinae Kiefer. Crustaceana 70: 901-910.

Reid, J.W. and Janetzky, W. (1996). Colonization of jamaican bromeliads by Tropocyclops jamaicensis $n$. sp. (Crustacea: Copepoda: Cyclopoida). Invertebrate Biology 115: 305-320.

Rylov, V.M. (1948). Freshwtaer Cyclopoida. Fauna SSSR, Crustaceans, 3(3): pp. 1-318. SSSR Academy of Sciences: Moscow, Leningrad. [in Russian] 
Shen, C.-J. and Tai, A.-Y. (1964). Description of new species of freshwater Copepoda from Kwangtung Province, South China. Acta Zootaxonomica Sinica 1: 367-396.

Shen, C.-J., Tai, A.-Y., Zhang, C.-Z., Li, Z.-Y., Song, D.X., Song, Y.-Z. and Chen, G.-X. (1979). Fauna Sinica, Crustacea, Freshwater Copepoda. Science Press: Peking. [in Chinese]

Stock, J.H. and Von Vaupel Klein, J.C. (1996). Mounting media revisited: the suitability of Reyne's fluid for small crustaceans. Crustaceana 69: 794-798.
Tang, D. and Knott, B. (2009). Freshwater copepods from the Gnangara Mound region of Western Australia. Zootaxa 2029: 1-70.

Tomikawa, K., Itô, T., Minakawa, N. and Mawatari, S.F. (2005). Two new species of Ochridacyclops Kiefer, 1937 (Copepoda, Cyclopoida) from Kenya and Nepal. Zoological Science 22: 477--487.

Manuscript received 29 March 2009; accepted 13 August 2009. 